УДК [378.091.33-057.86:51]:004

Осадча Катерина Петрівна

доцент, кандидат педагогічних наук, доцент кафедри інформатики і кібернетики

Мелітопольський державний педагогічний університет імені Богдана Хмельницького,

м. Мелітополь, Україна

ORCID ID 0000-0003-0653-6423

okp@mdpu.org.ua

\title{
ТЬЮТОРСЬКИЙ СУПРОВІД НАВЧАННЯ МАТЕМАТИКИ ЗАСОБАМИ ІНФОРМАЦІЙНО-КОМУНІКАЦІЙНИХ ТЕХНОЛОГІЙ
}

\begin{abstract}
Анотація. У статті висвітлено діяльність тьютора у процесі супроводу навчання математики на основі використання інформаційно-комунікаційних технологій (IКT). Автором проаналізовано наявні Інтернет-ресурси і мобільні додатки 3 математики, які класифіковано за їх функціональним призначенням на групи: системи масових відкритих курсів, платформи для адаптивного навчання, відео-канали, математичні онлайн тренажери, онлайн завдання, математичні ігри, математичні портали, онлайн платформи, математичні сайти, математичні онлайн середовища, математичні сервіси, мобільні додатки 3 математики (тренажери, ігри, генератори прикладів, програми-помічники, навчальні комплекси, калькулятори). Відповідно до вікових категорій тьюторантів IКТ з математики умовно поділено на три групи: для молодших школярів, учнів середньої школи та старшокласників. Здійснено короткий опис основних засобів ікт з навчання математики. Подано алгоритм побудови тьюторського заняття з їх використанням.
\end{abstract}

Ключові слова: тьютор; математика; інформаційно-комунікаційні технології; ресурси Інтернету; мобільні додатки.

\section{1. ВСТУП}

Постановка проблеми. Математика у школі часто є одним із складних для засвоєння предметів для учнів. Часто вони не в змозі на високому і навіть достатньому рівні опанувати математичні знання й уміння, ефективно засвоїти способи розв'язання математичних прикладів і вправ, а також не можуть самостійно підготуватися до контрольної роботи, ДПА чи ЗНО з математики. Традиційне розв'язання цієї проблеми батьки бачать у тому, щоб скористатися послугами репетитора, що у більшості випадків не досить ефективно сприяє її розв'язанню. Адже основна мета репетитора навчити або підтягнути учня 3 певного предмету. Його послугами найчастіше користуються учні з метою підготовки до вступних іспитів до вищого навчального закладу або для підвищення рівня володіння предметом. Репетитор проводить додаткові (індивідуальні) заняття, допомагаючи засвоїти необхідні знання. Проте у роботі з дітьми шкільного віку іноді потрібний інший підхід у навчанні математики. Їх потрібно переконати, що математика $\epsilon$ цікавим, захоплюючим i корисним $\mathrm{y}$ повсякденному житті предметом, з особливою ретельністю з'ясувати набутий учнем досвід, у чому саме потрібна допомога і якими шляхами іiі краще здійснити. Такі функції виконує тьютор, який забезпечує розробку і супровід індивідуальних освітніх програм учнів, організує процес індивідуальної роботи 3 учнями 3 виявлення, формування і розвитку їх пізнавальних інтересів, супроводжує процес формування їх особистості (допомагає їм розібратися в успіхах, невдачах, сформулювати особисте замовлення до процесу навчання, вибудувати цілі на майбутнє), координує пошук інформації учнями для самоосвіти $[1$, с. 3$]$. 
У процесі супроводу тьютор має запропонувати тьюторанту варіанти навчання математики, для чого він здійснює пошук освітніх ресурсів для створення індивідуальної освітньої програми і пропонує їх підопічному. Одними з таких ресурсів можуть бути Інтернет-ресурси та мобільні додатки, за допомогою яких тьютор може урізноманітнити свої заняття і сприяти самостійній роботі тьюторанта 3 метою напрацювання потрібних йому математичних умінь і навичок.

Аналіз останніх досліджень і публікацій. Проблема пошуку шляхів удосконалення математичної підготовки школярів за допомогою інформаційнокомунікаційних технологій (IКТ) досліджувалася Є. Ф. Вінниченком, М. І. Жалдаком, В. В. Корольським, Т. Г. Крамаренко,Т. О.Олійник, С. О. Семеріковим, С. В. Шокалюк та ін. Зокрема, М. І. Жалдак наголошує, що «впровадження засобів сучасних IКТ в навчальний процес дає можливість значно посилити зв'язок змісту навчання 3 повсякденним життям, надати результатам навчання практичної значимості, застосовності до розв'язування повсякденних життєвих проблем, задоволення практичних потреб, що є одним із аспектів гуманітаризації освіти» [2]. Те, що використання сучасних ІКТ у навчальному процесі впливає на його гуманізацію, також зазначає Є. Ф. Вінниченко, наголошуючи, що це також сприяє його інтенсифікації, підвищенню ефективності та наданню практичної значимості результатам навчання [3, c. 11]. Т. О. Олійник наголошує на тому, що IKT, зокрема пакети комп’ютерної алгебри та динамічної геометрії (Derive, GRAN, DG тощо) сприяють розвитку критичного мислення, формуючи здатність до всебічного глибинного аналізу та осмислення нового матеріалу, до виявлення внутрішніх особливостей і причин різноманітних явищ; розвиваючи відкритість щодо нових відомостей та неприйняття на віру фактів за безпосереднього сприймання, навички пошуку нестандартних способів розв'язування поставлених завдань й прийняття рішень, уміння розумного вибору між конкуруючими ідеями та формуванню оригінальних думок тощо [4].

У навчальному посібнику [5] автори подають методичні рекомендації щодо використання у навчанні математики таких інформаційно-комунікаційних засобів як програмно-методичні комплекси «Математика, 5 клас» та «ТерМ», бібліотеки електронної наочності «Алгебра, 7-9 клас» та «Геометрія, 7-9 клас», педагогічні програмні засоби «Алгебра, 11 клас», GRAN1 та «Геометрія, 11 клас», динамічна геометрія GRAN-2D, GRAN-3D, а також дистанційні технології та мережні системи комп'ютерної математики.

Аналіз наукових праць показав, що аспекти тьюторського супроводу старшокласників на уроках математики розглядав I. В. Фуфачев [6], шляхи забезпечення індивідуальної освітньої траєкторії у математичній освіті аналізували Л. Ю. Уразаєва та Т. В. Піхотіна, проблему значущості тьюторського супроводу в інформаційно-комунікаційному просторі досліджували Т. О. Кузьміна і I. М. Семенова [7].

У статті [8] було запропоновано комплекс інформаційно-комунікаційних засобів для кожного з основних етапів технології тьюторського супроводу, а саме програми та ресурси для онлайн тестування, конструктори тестів, програмні засоби для проведення «мозкових штурмів» (онлайн дошки, інтелект-карти), системи управління цілями та завданнями (планувальники, календарі, органайзери), пошукові інструменти, агрегатори інформації, сховища графічних і відеоматеріалів, програми і сервіси для створення мультимедійного контенту та електронних навчальних матеріалів, програми для створення портфоліо (офісні програми, сервіси створення портфоліо, сервіси створення електронних книг) тощо. 
Проте у науковій думці не достатньо висвітлено питання використання математичних інформаційно-комунікаційних технологій у роботі тьютора 3 дітьми шкільного віку.

Мета статті. Метою статті $\epsilon$ здійснення аналізу засобів інформаційнокомунікаційних технологій математичного спрямування, зокрема ресурсів мережі Інтернет та мобільних додатків, для організації тьюторського супроводу дітей шкільного віку.

\section{2. ТЕОРЕТИЧНІ ОСНОВИ ДОСЛІДЖЕННЯ}

Під тьюторським супроводом розуміють педагогічну діяльність з індивідуалізації навчання, спрямовану на виявлення i розвиток освітніх мотивів та інтересів тьюторантів, пошук освітніх ресурсів для створення індивідуальної освітньої програми, на роботу з освітнім замовленням, формування навчальної й освітньої рефлексії того, хто навчається [9, с. 240].

Тьюторський супровід включає освітню, соціальну та психологічну діяльність, що спрямована на навчання, контроль, допомогу, коригування, адаптацію тьюторантів у досягненні ними їх запланованих освітніх цілей. Тьютор допомагає учневі визначитися 3 уподобаннями, 3 напрямком творчої або дослідницької діяльності, справлятися 3 труднощами в процесі отримання освіти. I, найголовніше, він організовує максимально комфортні умови для реалізації освітнього запиту тьюторанта як особистості.

Для цього, як зазначає Е. О’Брайант, тьютор має виконувати три основні правила тьюторингу [10, с. 13-24].

1. «Роби перший крок». Потрібно визначити досвід підопічного і причини його не успіху, з'ясувати його стиль навчання, цілі, сильні і слабкі сторони, інтереси, стиль мислення, мотивацію до навчання тощо. Це допоможе встановити особистий контакт 3 учнем і намітити ефективні стимули і підходи до роботи з ним.

2. «Завоюйте довіру, потім слухайте». Пояснивши, у чому полягає роль тьютора, розповівши учню про, те, що в школі самому здавалося складним, тьютор дає йому зрозуміти, що він на його боці: співчуває його труднощам, радіє разом з ним його перемогам, спілкується як з рівним, надаючи вибір та сприймаючи критику.

3. «Наводьте мости». Після з'ясування, у якому предметі підопічний орієнтується краще та що його цікавить, тьютору доцільно починати заняття з цього, прокладаючи місточок від знайомого і легкого до невідомого і складного.

Стосовно занять з математики Е. О’Брайант радить дотримуватися таких правил [10, c. 49-50].

1. Заспокоюйте страхи учнів і розповідайте, як любите математику самі.

2. Не жалійте часу на те, щоб розібратися, що вже знає учень, а з чим йому треба допомогти.

3. 3'ясуйте, що його цікавить, і побудуйте на цьому заняття. Придумайте, як використовувати в них посилання до літературних творів, комп'ютерних ігор, автомобілів, архітектури, музики і т. д.

4. За першої-ліпшої можливості намагайтеся поясняти матеріал за допомогою кінестетичних прийомів - через дії й відчутні приклади.

5. За необхідності використовуйте прийоми боротьби 3 хвилюванням на зразок глибокого дихання і фізичних вправ, адже сильний жах вимикає ті зони мозку, які використовуються для розв'язання математичних задач.

Основним завданням тьюторського супроводу у математичній освіті є розробка разом із тьюторантом індивідуальної освітньої програми 3 удосконалення математичних компетентностей та їі уточнення у вигляді індивідуального освітнього 
маршруту. Завдання тьютора у цьому процесі полягає у тому, щоб зробити тьюторанта максимально самостійним, але при цьому контрольованим суб'єктом у процесі досягнення своєї освітньої цілі. Для цього доцільним вважаємо застосування інформаційно-комунікаційних технологій, а саме математичних Інтернет-ресурсів та мобільних додатків.

\section{3. РЕЗУЛЬТАТИ ДОСЛІДЖЕННЯ}

Нами було здійснено пошук й аналіз наявних у всесвітній мережі ресурсів для підтримки процесу навчання математики. Ми ставили за мету знайти та проаналізувати більшою частиною україномовні ресурси і мобільні додатки українських виробників, адже вони найбільше адаптовані до вітчизняних освітніх вимог і навчальних програм. Як критерій класифікації нами було обрано таку характеристику мережних ресурсів як їх загальне призначення. Грунтуючись на описі мережних ресурсів та аналізуючи їхні функціональні особливості у навчанні математики, ми з'ясували, що існують тематичні ресурси з математики у системах масового відкритого навчання, ресурси для реалізації адаптивного навчання 3 математики, перегляду відео, тренування математичних навичок, розв'язання математичних завдань 3 різних розділів математики, ігрової діяльності, а також для поєднання різних освітніх послуг в одному ресурсі, надання великої кількості різноманітних завдань з розвитку логічного мислення, створення динамічних математичних моделей, пошуку і створення інтерактивних навчальних матеріалів 3 математики. Окремо також було виділено додатки 3 математики, з якими можна працювати з мобільного телефону (смартфону) чи планшетного комп'ютера, та Інтернет-ресурси загальнотеоретичного і методичного характеру, які містять методичні та дидактичні матеріали для вчителів. Тому IКТ з математики ми класифікували відповідно за типами на такі дванадцять груп: системи масових відкритих курсів, платформи для адаптивного навчання, відео-канали, математичні онлайн тренажери, онлайн завдання 3 математики, математичні ігри, математичні портали, математичні онлайн платформи, математичні онлайн середовища, математичні сервіси, мобільні додатки з математики, навчальні сайти з математики (табл. 1).

Таблиия 1

\section{Класифікація математичних Інтернет-ресурсів за типами}

\begin{tabular}{|c|c|c|c|c|}
\hline $\begin{array}{l}\text { № } \\
3 / \text { II }\end{array}$ & Тип & Приклад & Інтернет-адреса & $\begin{array}{c}\text { Призначення на } \\
\text { заняттях } 3 \text { математики }\end{array}$ \\
\hline 1 & $\begin{array}{l}\text { Система } \\
\text { масових } \\
\text { відкритих } \\
\text { курсів }\end{array}$ & Академія Хана & uk.khanacademy.org & $\begin{array}{l}\text { Використання відео-лекцій, } \\
\text { тестів та інших матеріалів } \\
\text { окремо або у межах одного } \\
\text { курсу } 3 \text { метою вивчення, } \\
\text { закріплення, актуалізації } \\
\text { навчального матеріалу }\end{array}$ \\
\hline 2 & $\begin{array}{l}\text { Ресурс для } \\
\text { адаптивного } \\
\text { навчання }\end{array}$ & Knewton & knewton.com & $\begin{array}{l}\text { Персоналізація освітнього } \\
\text { контенту, аналіз } \\
\text { успішності учнів }\end{array}$ \\
\hline \multirow[b]{2}{*}{3} & \multirow[t]{2}{*}{$\begin{array}{l}\text { Математич- } \\
\text { ний } \quad \text { відео- } \\
\text { канал }\end{array}$} & MathTutor & $\begin{array}{l}\text { youtube.com/user/MathTut } \\
\text { or } 777 / \text { playlists }\end{array}$ & $\begin{array}{l}\text { Перегляд відео для вивчення } \\
\text { нових тем }\end{array}$ \\
\hline & & $\begin{array}{l}\text { Презентації } \\
\text { математики }\end{array}$ & $\begin{array}{l}\text { https://www.youtube.com/ } \\
\text { channel/UCfMCioi- } \\
\text { A1PVTONy68rzlSA }\end{array}$ & Презентації з математики \\
\hline 4 & $\begin{array}{l}\text { Математичні } \\
\text { онлайн }\end{array}$ & $\begin{array}{l}\text { Tренажери і тести } \\
3 \text { математики i }\end{array}$ & test-trainer.com.ua & $\begin{array}{l}\text { Відпрацювання } \\
\text { розв'язувати приклади і задачі }\end{array}$ \\
\hline
\end{tabular}




\begin{tabular}{|c|c|c|c|c|}
\hline & \multirow[t]{2}{*}{ тренажери } & фізики & & \multirow[t]{2}{*}{$\begin{array}{l}\text { різного типу на теми з окремих } \\
\text { розділів математики }\end{array}$} \\
\hline & & Самоучка & $\begin{array}{l}\text { samouchka.com.ua/ukr/_m } \\
\text { atematyka }\end{array}$ & \\
\hline 5 & $\begin{array}{l}\text { Онлайн } \\
\text { завдання } \\
\text { математики }\end{array}$ & Оценок.net & ozenok.net/math & $\begin{array}{ll}\text { Закріплення } & \text { матеріалу } \\
\text { математики } & \end{array}$ \\
\hline \multirow[b]{2}{*}{6} & \multirow{2}{*}{$\begin{array}{l}\text { Математичні } \\
\text { ігри }\end{array}$} & Johnnie'sMathPage & jmathpage.com & \multirow{2}{*}{$\begin{array}{l}\text { Мотивація і зацікавлення до } \\
\text { навчання } \\
\text { закріплення матеріалу }\end{array}$} \\
\hline & & Mathplayground & $\begin{array}{l}\text { mathplayground.com/gam } \\
\text { es2.html }\end{array}$ & \\
\hline 7 & $\begin{array}{l}\text { Математич- } \\
\text { ний портал }\end{array}$ & ЯКлас & yaklas.com.ua & $\begin{array}{lr}\text { Підготовка } & \text { до } \\
\text { контрольних } & \text { робіт, } \\
\text { математичні } \\
\text { тренажери }\end{array}$ \\
\hline 8 & $\begin{array}{l}\text { Математична } \\
\text { онлайн } \\
\text { платформа }\end{array}$ & Logiclike & logiclike.com & $\begin{array}{l}\text { Цікаві додаткові завдання } \\
\text { розвиток алгоритмічного } \\
\text { логічного мислення } \\
\text { ло }\end{array}$ \\
\hline 9 & $\begin{array}{l}\text { Математичне } \\
\text { онлайн } \\
\text { середовище }\end{array}$ & GeoGebra & geogebra.org & $\begin{array}{lr}\text { Дидактичні } & \text { матеріали } 3 \\
\text { математики, } & \text { створення } \\
\text { динамічних } & \text { математичних } \\
\text { моделей } & \\
\end{array}$ \\
\hline 10 & $\begin{array}{l}\text { Математичні } \\
\text { сервіси }\end{array}$ & WolfrAmalpha & wolframalpha.com & $\begin{array}{lrr}\text { Створення } & \text { i } & \text { використання } \\
\text { iнтерактивних } & \text { навчальних } \\
\text { матеріалів } & \text { з } \\
\text { розв'язання } & & \text { математикичй } \\
\text { завдань } & \end{array}$ \\
\hline \multirow{4}{*}{11} & \multirow[t]{4}{*}{$\begin{array}{l}\text { Мобільні } \\
\text { додатки } \\
\text { математики }\end{array}$} & Geeksmath & $\begin{array}{l}\text { play.google.com/store/app } \\
\text { s/details?id=com.cloudco } \\
\text { mputingcenter.matan }\end{array}$ & $\begin{array}{l}\text { Математичні ігри для } \\
\text { тренування логіки }\end{array}$ \\
\hline & & PhotoMath & $\begin{array}{l}\text { play.google.com/store/app } \\
\text { s/details?id=com.micoblin } \\
\text { k.photomath\&hl }\end{array}$ & $\begin{array}{l}\text { Засвоєння теоретичних питань } \\
\text { i закріплення способів } \\
\text { розв'язування математичних } \\
\text { задач }\end{array}$ \\
\hline & & $\begin{array}{l}\text { Математичні } \\
\text { хитрощі }\end{array}$ & $\begin{array}{l}\text { play.google.com/store/app } \\
\text { s/details?id=example.math } \\
\text { arithmetics }\end{array}$ & Поетапне розв’язання задач \\
\hline & & $\begin{array}{l}\text { Математичні } \\
\text { завдання Кенгуру }\end{array}$ & $\begin{array}{l}\text { play.google.com/store/app } \\
\text { s/details?id=com.androidg } \\
\text { ame.gamefree.kangaroo }\end{array}$ & $\begin{array}{l}\text { Проведення обчислень, } \\
\text { математичних експериментів }\end{array}$ \\
\hline \multirow{8}{*}{12} & \multirow{8}{*}{$\begin{array}{l}\text { Навчальний } \\
\text { сайт } \\
\text { математики }\end{array}$} & Formula & formula.co.ua & \multirow{8}{*}{$\begin{array}{lr}\text { Пояснення } & \text { тем, } \\
\text { розв'язування } & \text { патематичндих } \\
\text { завдань, } & \text { закріплення } \\
\text { пройденого } & \text { матеріалу, } \\
\text { методичні } & \text { матеріали для } \\
\text { вчителів, } & \text { додаткове } \\
\text { математичне } & \text { програмне } \\
\text { забезпечення, підготовка до } \\
\text { ДПА, ЗНО та олімпіад }\end{array}$} \\
\hline & & Жива математика & shahist.at.ua & \\
\hline & & $\begin{array}{l}\text { Історична мозаїка } \\
\text { в математиці }\end{array}$ & ist-matemat.at.ua & \\
\hline & & $\begin{array}{l}\text { Сайт творчо } \\
\text { працюючих } \\
\text { учителів } \\
\text { математики }\end{array}$ & $\begin{array}{l}\text { sites.google.com/site/visua } \\
\text { lmatem/informacia-pro- } \\
\text { vciteliv }\end{array}$ & \\
\hline & & $\begin{array}{l}\text { Математика } \\
\text { школі онлайн }\end{array}$ & $\begin{array}{l}\text { sites.google.com/site/mate } \\
\text { matikaonlajn }\end{array}$ & \\
\hline & & $\begin{array}{l}\text { Імперія } \\
\text { математики }\end{array}$ & i-math.com.ua & \\
\hline & & $\begin{array}{l}\text { Математичний } \\
\text { олімпіадний рух } \\
\text { України }\end{array}$ & matholymp.org.ua & \\
\hline & & Математика & $\begin{array}{l}\text { katerinapokolodnaya.blogs } \\
\text { pot.com }\end{array}$ & \\
\hline
\end{tabular}


Також вважаємо доцільним умовно розділити проаналізовані ІКТ відповідно до вікових особливостей учнів на засоби для молодших школярів (наприклад, Презентації 3 математики, Самоучка, Оценок.net, Johnnie'sMathPage, Mathplayground, ЯКлас, Formula та ін.), учнів середньої школи (наприклад, MathTutor, Презентації 3 математики, Оценок.net, Johnnie'sMathPage, Mathplayground, ЯКлас, Formula, Geeksmath та ін.) та старшокласників (наприклад, Академія Хана, Knewton, MathTutor, Презентації 3 математики, Тренажери і тести з математики i фізики, Formula, WolfrAmalpha, Geeksmath та ін.).

Опишемо коротко найякісніші Інтернет-ресурси і мобільні додатки з математики.

Платформа Knewton пропонує скористатися інтегрованими адаптивними курсами, які розроблені за допомогою платформи, або розробити тьютору свій власний курс для одного підопічного або групи учнів. Особливістю платформи $\epsilon$ те, що вона використовує технології аналізу даних у сфері освіти; може бути підключена до будьякої сучасної системи управління навчальним процесом (LMS); за допомогою інтуїтивної панелі тьютор може відстежувати поточні теми, дії і результати навчання тьюторанта, проблеми у навчанні, а також отримувати повідомлення, що інформують, які учні або теми вимагають негайної уваги.

Методологія Knewton будується навколо двох основних понять: технології планування освітньої траєкторії і складної моделі оцінки учня. Адаптивне навчання в розумінні Knewton має реагувати в реальному часі на результати окремого учня і його дій в системі (рис. 1). Цей підхід збільшує ймовірність того, що учень отримає правильний освітній контент у потрібний момент і досягне поставлених перед собою цілей. Наприклад, якщо учень погано справляється 3 певним набором питань, то Knewton зможе припустити, які теми в цьому списку питань виявилися незрозумілими, і запропонувати йому контент, який допоможе підвищити рівень розуміння саме цих тем[11].
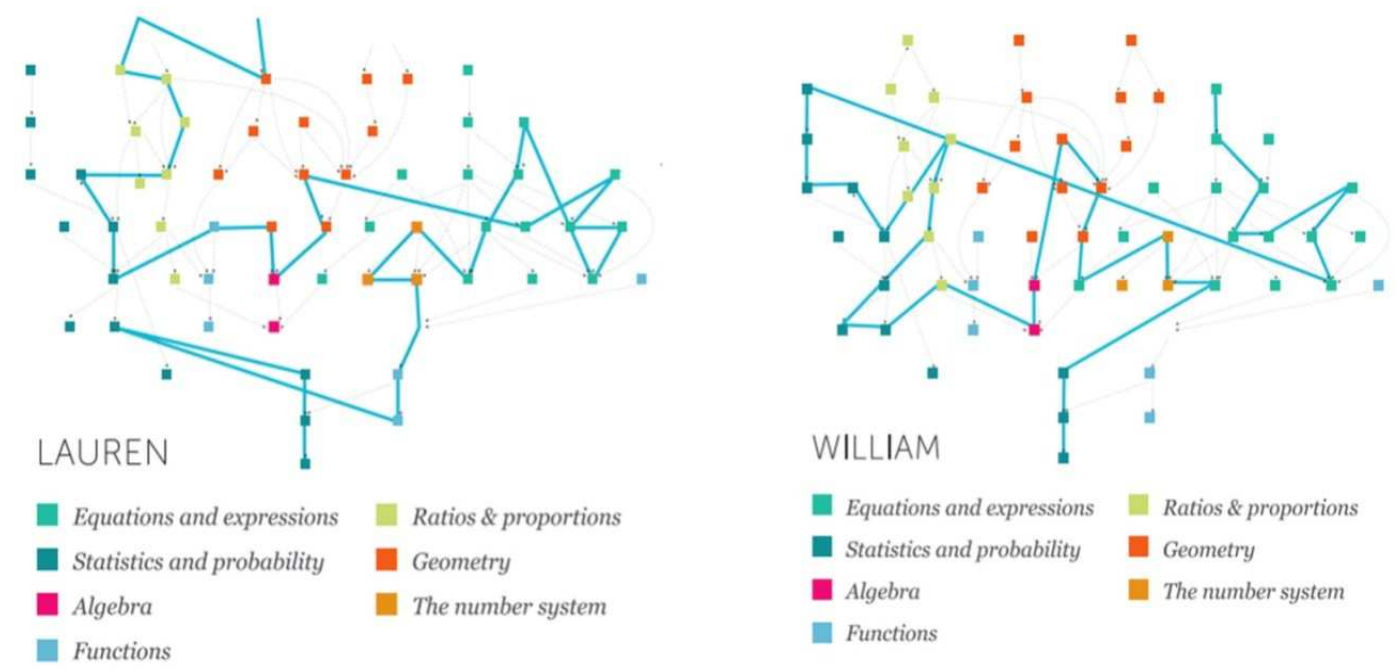

Рис. 1. Індивідуальні освітні траєкторії учнів у Кпештоп (джерело [11])

За допомогою адаптивних можливостей платформи тьютор може відслідкувати індивідуальну траєкторію навчання свого підопічного, тобто: які теми і розділи були ним пройдені, у якому темпі, у якій послідовності, які теми чи завдання викликали труднощі. Орієнтуючись на це, тьютор запропонує сам повторити не достатньо засвоєний тьюторантом матеріал або засобами платформи Knewton допоможе підопічному удосконалити свої знання з проблемних тем. 
Сайт «ЯКлас» позиціонується як ресурс, спрямований допомогти батькам визначити готовність дитини до контрольної або іспиту та додатково підготувати іiї до шкільних занять, а також учням - повторити потрібну тему, підготуватися до екзаменів i контрольних робіт, перевірити свої знання, отримати покрокові інструкції до розв'язання всіх завдань на сайті, позмагатися у знаннях 3 математики 3 іншими учнями, поспілкуватися з ровесниками; учителям - проводити перевірочні, тестові та контрольні роботи, проводити діагностику знань учнів, а також заняття в комп'ютерному класі. Сайт розроблений на основі платформи генерації завдань GenExis, яка дозволяє створити необмежену кількість вправ з одного шаблону вправи, надає можливість подання покрокового розв'язку задачі і здійснювати автоматизований контроль перевірки домашніх завдань, тестів, контрольних і екзаменів [12].

Онлайн-платформа LogicLike базується на методиці розвитку логічного мислення i математичних здібностей для дітей 5-12 років, розробленої докторами наук, педагогами вищої категорії, досвідченими методистами і психологами Білорусі. Вона має такі основні блоки: «Завдання і теорія», «Відео-лекції», «Минулі олімпіади», «Логічні ігри», «Олімпіади», «Довідник», «Моя сторінка», «Сертифікати», «Мої значки», «Бонуси», «Повідомлення», «Налаштування». У блоці «Завдання і теорія» пропонуються завдання на розвиток логічного мислення трьох рівнів (Базовий, Просунутий, Експерт), а саме таких типів: «Фігури. Розгортки. Відображення», «Істина i брехня», «Класичні логічні завдання», «Математичні ребуси», «Закономірності», «Перестановки», «Алгоритми». «Завдання на шаховому полі», «Звукові схеми», «Переливання і зважування», «Стільники. Судоку. Японські кросворди» (рис. 2).

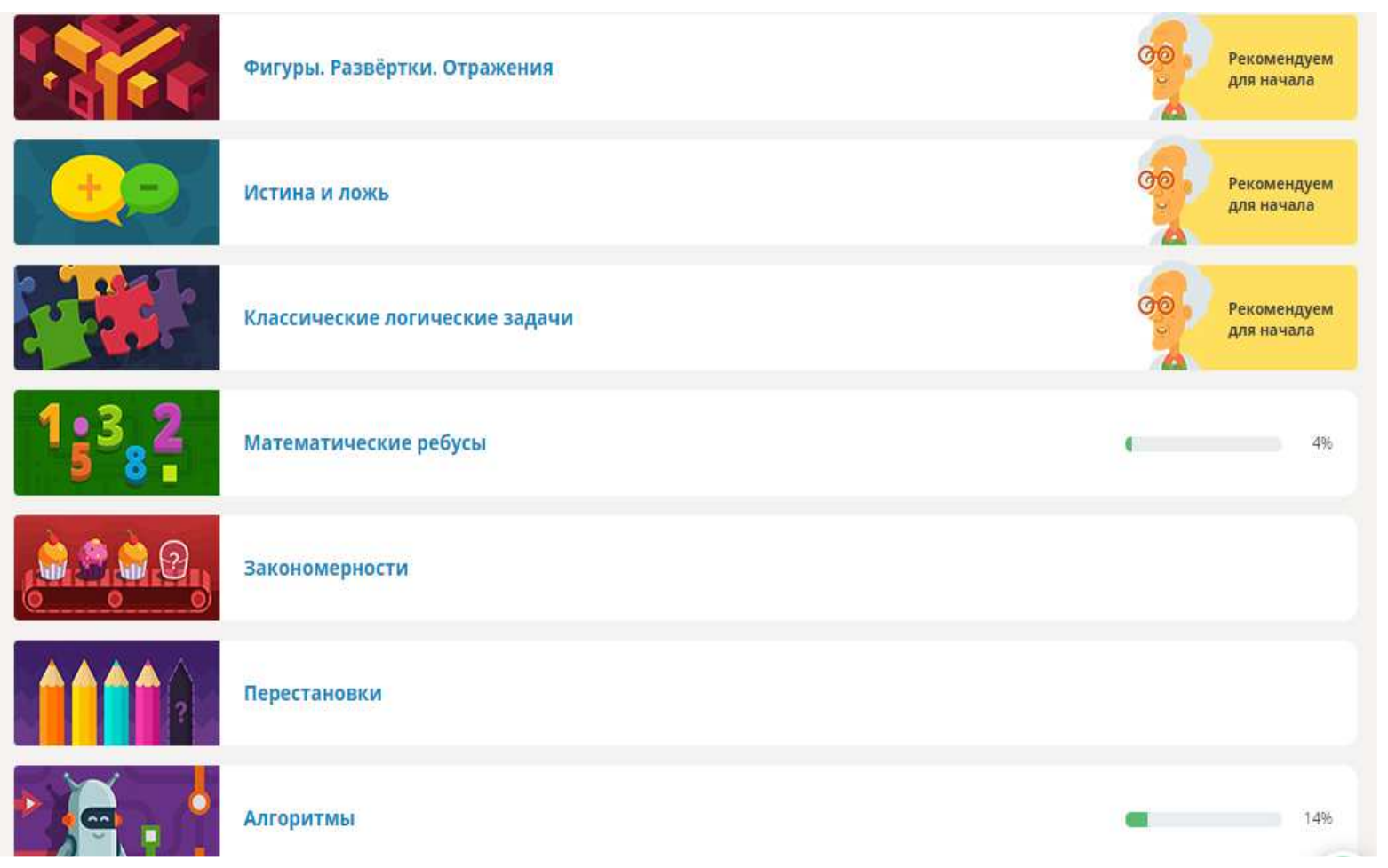

Pис. 2. Перелік типів завдань у блоиі «Завдання і теорія» онлайн платформи LogicLike

У розділі «Минулі олімпіади» розміщуються тести пройдених олімпіад для різних класів з відповідями та коментарями. Розділ «Логічні ігри» містить ігри, розроблені спеціально для платформи, наприклад, гра LOGIC Шульте базується на популярних 
методиках таблиці Шульте основна мета яких - розвинути периферійний зір i поліпшити навички швидкого читання. У розділі «Олімпіади» представлені всі значущі події центру Logic, а також заходи районного та міського рівня. «Довідник» пропонує допомогу в роботі з онлайн платформою та рекомендації, як займатися і в якій послідовності виконувати завдання.

Завдяки цій онлайн платформі тьютор, добре знаючи недоліки у вивченні математики своїм підопічним, може обрати цікаві для нього додаткові завдання, які відповідають віковій категорії тьюторанта, для розвитку його алгоритмічного i логічного мислення. В ігровій формі у LogicLike тьюторант може проходити різні завдання, змагаючись з іншими користувачами, що також стимулює до прояву його активності у навчанні математики.

GeoGebra $є$ динамічним програмним забезпеченням математики, яке поєднує геометрію, алгебру і математичний аналіз. 3 одного боку, GeoGebra це інтерактивна система геометрії, у якій можна зробити конструкції точок, векторів, відрізків, прямих, багатокутників і конічних перетинів, а також функції та їх динамічні зміни. 3 іншого боку, рівняння і координати можуть бути введені безпосередньо, i так, GeoGebra може працювати зі змінними чисел, векторів і точок [13]. Цікавим для учнів буде те, що 3 використанням такого засобу IKT як GeoGebra у процес навчання математики додається рух завдяки анімації. Тепер там, де раніше вчитель, малюючи фігури біля дошки, лише закликав уявити те чи інше переміщення (у геометрії, у «задачах на рух»), його можна змоделювати на дисплеї комп'ютера. GeoGebra дозволяє анімувати не тільки вільні числа і / або кути, в один і той же час, але також залежні точки, які обмежені на об'єкті (сегменти, лінії, функції, вигин і т. д.). GeoGebra дозволяє візуалізувати математику, проводити експерименти і дослідження під час розв'язування математичних завдань не тільки геометричного характеру. 3 методичної точки зору середовище GeoGebra дозволяє створювати на екрані комп'ютера креслення, які можна використовувати на різних стадіях вивчення навчального матеріалу, від креслень ілюстративного характеру (живих плакатів) до дослідних креслень. Особливо пізнавальним і захоплюючим є сам процес створення відповідного малюнка, анімації чи 3D-ілюстрації. GeoGebra має онлайн, десктопний та мобільний варіанти, що урізноманітнює роботу з цим програмним забезпеченням.

Використовуючи засоби динамічного моделювання у цьому середовищі, обираючи завдання відповідно до індивідуальної освітньої програми тьюторанта, тьютор сприятиме підвищенню інтересу до навчання математики, а й розвиватиме математичну інтуїцію. Доцільний добір динамічних моделей з урахуванням вікових особливостей підопічного надасть тьютору нові можливості для виконання його освітнього запиту щодо ефективного навчання математики.

WolfrAmalpha - англомовний безкоштовний обчислювальний онлайн рушій, що генерує відповіді у режимі реального часу, здійснюючи обчислення і пошук даних по своїй великій базі знань, яка містить дані 3 математики, фізики, астрономії, хімії, біології, медицини, історії, географії, політики, музики, кінематографії, а також інформацію про відомих людей та інтернет-сайти. У навчанні математики він допоможе знайти теоретичні й історичні відомості 3 предмету, дані наукових експериментів за темами, створити візуальні засоби для презентацій і роздаткових матеріалів, намалювати графік функції (рис. 3), надати покрокове розв'язання прикладу. Отже, WolfrAmalpha можна використовувати для призначення завдань на основі інформації, що міститься у ньому, для науково-дослідних робіт і проектів [14]. 


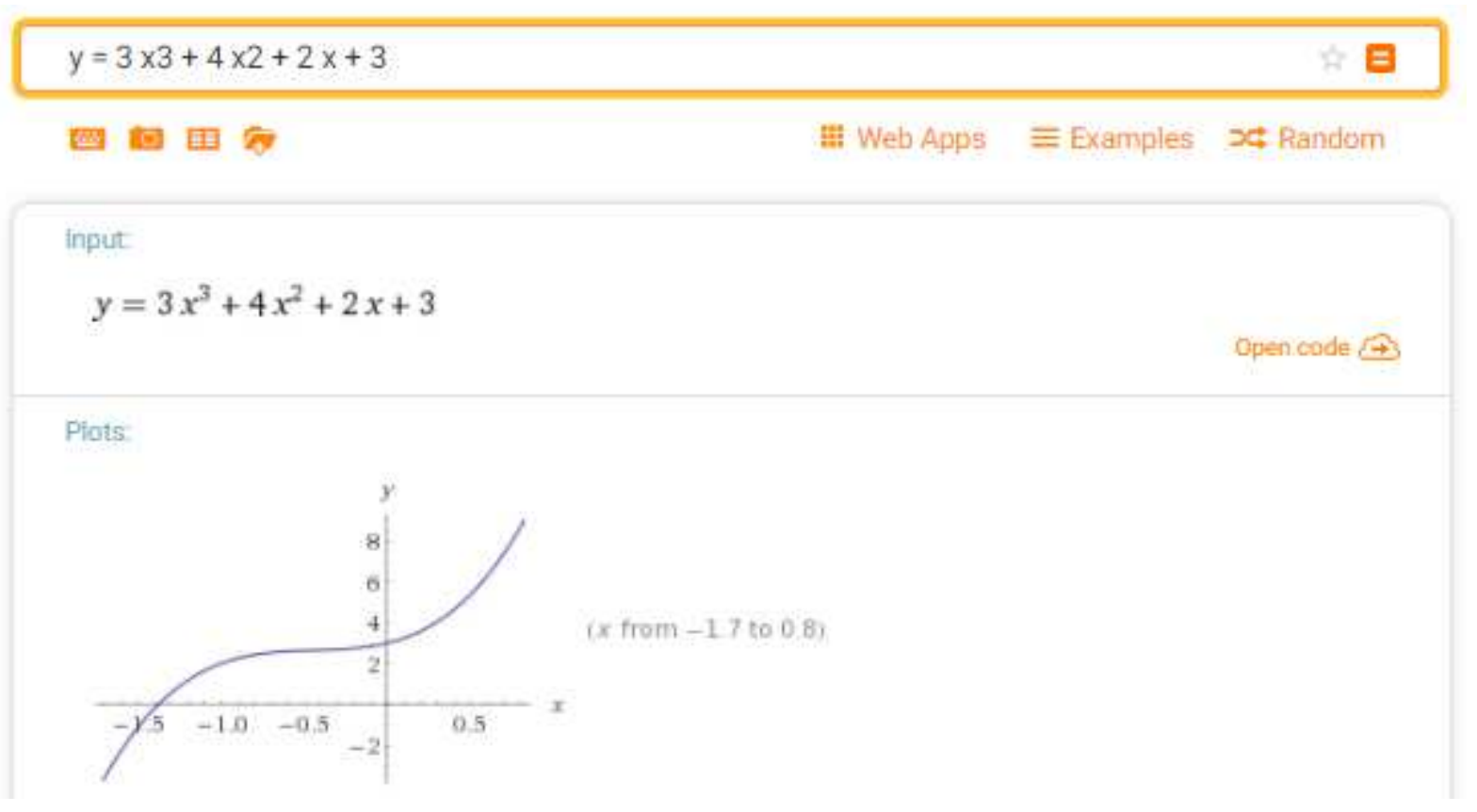

Pис. 3. Побудова графіку функиій у WolfrAmalpha

У роботі з цим ресурсом для тьютора відкривається багато можливостей для того, щоб надати своєму підопічному уявлення про практичне значення математичних розрахунків і мотивувати його до вивчення математики як життєво необхідного предмету. Наприклад, підрахунок калорій, малювання графіку у вигляді серця або котиків за допомогою використання математичних кривих у прямокутній декартовій системі координат разом з відповідними параметричними рівняннями цих кривих та інші цікаві завдання, що відповідають віковим особливостям тьюторанта, сприятимуть зростанню його інтересу до математики. За допомогою WolfrAmalpha тьютор може навчити підопічного ефективно обробляти великі масиви даних i представляти їх у вигляді різних графіків, діаграм і таблиць, що допоможе засвоєнню тьюторантом статистичних методів аналізу даних.

Тьютор, на відміну від учителя i репетитора, основним завданням яких $\epsilon$ передавати знання й уміння, допомагає дитині у самоосвіті, показі шляхів самонавчання i саморозвитку, пропонуючи тьюторанту різноманітні варіанти для цього, у тому числі і засоби IКТ. Тому використання IКТ з математики урізноманітнює засоби навчання, які може використовувати тьютор у своїй діяльності. Різноманіття мобільних додатків дає можливість тьютору застосовувати їх для розв'язання різних завдань у роботі з тьюторантом.

Наприклад, мобільний додаток PhotoMath тьютору доцільно запропонувати для пошуку самостійного розв'язку тьюторантом математичних прикладів. Цей додаток $є$ математичним калькулятором, який використовуючи камеру смартфона, розпізнає математичний приклад і пропонує розв’язання. Додаток має функцію розпізнавання рукописного тексту, та редагування розпізнаного запису прикладу. У платній версії PhotoMath надає покрокові інструкції розв'язання прикладів, використовує барвисті пояснення, надає поради і рекомендації, а також пропонує миттєве розв'язання мільйонів прикладів (рис. 4). 


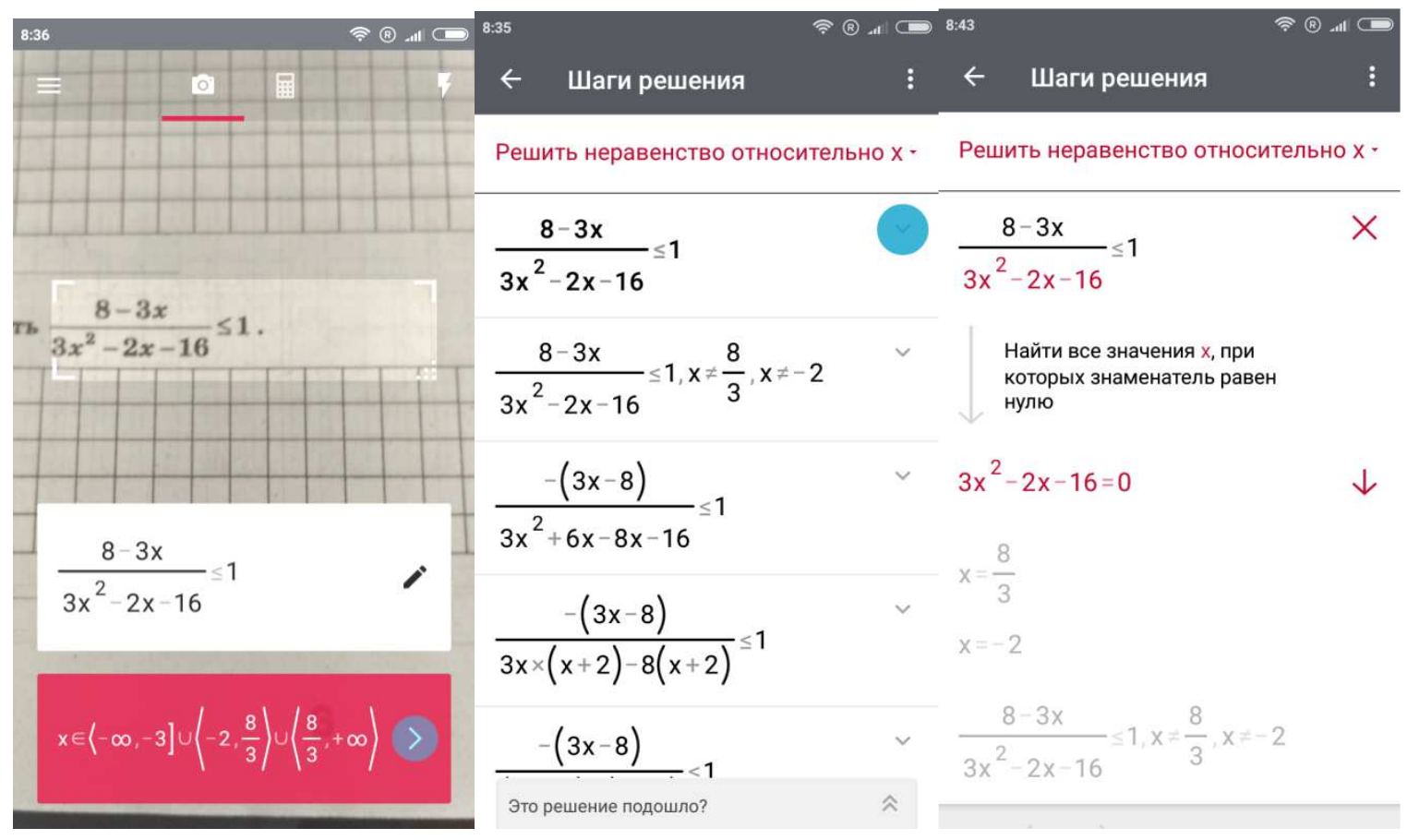

Рис. 4. Приклад роботи мобільного додатку PhotoMath

Додаток «Математика на Дошці» $є$ анімаційною грою, що допомагає засвоювати навички усного рахунку для користувачів 5 вікових категорій (дошкільний, 1 клас, 2 клас, 3 клас, діти 12+ і дорослі) 3 відповідними темами: додавання, віднімання, порівняння, числовий ряд, таблиця множення i ділення, змішані вирази. Усі математичні вправи згруповані за рівнями відповідно до їх складності. Для переходу на наступний рівень необхідно правильно вирішити всі вправи поточного рівня. Загалом у додатку міститься більш ніж 3000 математичних вправ за різними темами. Багатомовний інтерфейс у вигляді шкільної дошки створює уявлення про присутність у класі. Статистика, що ведеться у додатку, показує кількість пройдених рівнів за темами. Використовуючи цей мобільний додаток, тьютор не тільки зможе відпрацювати 3 підопічним теми, що викликають у нього труднощі, а, використовуючи ігровий момент, зацікавить його у вивченні математики.

Мобільний додаток «Майстер Математики», крім тренування розв'язання математичних прикладів, допоможе тьютору розвинути у тьюторанта вміння рахувати в умі, абстрактне і логічне мислення, інтелект, посидючість та підвищити рівень IQ. Для цього у додатку є такі можливості: завдання на додавання, віднімання, множення та ділення; комбінований режим МІКС; більше ніж 150 рівнів; присвоєння досягнення googleplay (за отримання максимальної кількості балів, за закінчення рівнів 3 максимальною кількістю зірок тощо); таблицю рекордів; простий, зрозумілий багатомовний інтерфейс; безкоштовність.

Мобільний додаток Test [15] призначений для тренування тестів із 3НО, у тому числі з математики. У базі програми містяться тести з усіх предметів з 2007 до 2013 року проведення ЗНО. Можна обрати рік, режим проходження (вибірковий чи повністю). Після закінчення проходження тестування у режимі «Пройти повністю» можна натиснути на кнопку звіт, у результаті чого буде виведено результат проходження з вказівками на помилки. Такий додаток тьютор може використовувати у роботі із старшокласниками як для перевірки знань з математики, так і для тренування.

3 аналізу Інтернет-ресурсів і мобільних додатків можемо зробити висновок про недостатню кількість україномовних математичних ігор для різних вікових категорій 
учнів на різноманітні теми з математики, алгебри і геометрії. Тому можна скористатися англомовними (jmathpage.com,kidsmathgamesonline.com, mathplayground.com, mathgames.com, sheppardsoftware.com/math.htm) або російськомовними (quicksave.su/math-games, onlineguru.ru/math) сайтами.

Зважаючи на значний арсенал IКТ з математики, пропонуємо приклад алгоритму проведення тьюторського заняття з використанням математичних засобів IКТ.

1. Пояснення нового матеріалу з використанням відеороликів на відео каналі MathTutor або у системі масових відкритих курсів Академія Хана 3 українським перекладом.

2. Тренування 3 розв'язання прикладів за темою за допомогою мобільних (Математика на Дошці) чи онлайн тренажерів (test-trainer.com.ua).

3. Закріплення матеріалу за допомогою матеріалів сайтів ЯКлас, Оценок.net aбо LogicLike,де підопічний у змагально-ігровій формі виконує цікаві завдання 3 математики.

4. Заохочення i мотивація до навчання математики через використання комп'ютерних ігор на сайтах «Johnnie'sMathPage» та «Mathplayground».

5. Виконання домашнього завдання на платформі для адаптивного навчання.

Зауважимо, що такий алгоритм не $є$ універсальним, адже застосування на кожному занятті такого арсеналу IКT може негативно вплинути на результати тьюторського супроводу. Мета тьютора уважно і чуйно ставитися до підопічного i, враховуючи завдання індивідуальної освітньої програми, у процесі тьюторського супроводу задіяти ті IКТ, які будуть доцільними за певних освітніх завдань, за умови комфортної організації процесу досягнення індивідуальних освітніх цілей тьюторанта та його позитивного ставлення до використання запропонованих засобів IКТ.

\section{4. ВИСНОВКИ ТА ПЕРСПЕКТИВИ ПОДАЛЬШИХ ДОСЛІДЖЕНЬ}

Отже, залежно від того, яку мету на занятті ставить тьютор, у ході тьюторського супроводу підопічного під час навчання математики, можуть застосовуватися різні Інтернет-ресурси чи мобільні додатки. Інтенсивний розвиток ІКТ надає все більше можливостей для урізноманітнення тьюторских практик навчання математики. Останнім часом з'являється все більше україномовних засобів IКТ з математики, на яких ми зробили акцент під час аналізу i запропонували алгоритм проведення тьюторського заняття з використанням математичних засобів IКТ.

У подальших дослідженнях планується провести дослідження щодо ефективності використання проаналізованих математичних IКТ у процесі тьюторського супроводу дітей шкільного віку.

\section{СПИСОК ВИКОРИСТАНИХ ДЖЕРЕЛ}

[1] В. П. Сергеева, И. С. Сергеева, Г. В. Сороковых, и Ю. В. Зиборова, Тьютор в образовательном пространстве. Москва, Россия: ИНФРА-М, 2016.

[2] М. І. Жалдак, "Педагогічний потенціал комп'ютерно-орієнтованих систем навчання математики". [Електронний ресурс]. Режим доступу: http://ii.npu.edu.ua/files/Zbirnik_KOSN/7/1.pdf.Дата звернення: травень, 26, 2017.

[3] Є. Ф. Вінниченко, "Розвиток творчих здібностей старшокласників у процесі навчання інформаційних технологій розв'язування математичних задач", автореф. дис. канд. пед. наук, Нац пед. ун-т ім. М. П. Драгоманова. Київ, 2006.

[4] Т. О. Олійник, "Використання ІКТ для розвитку критичного мислення". [Електронний ресурс]. Режим доступу: http://enpuir.npu.edu.ua/bitstream/123456789/1300/1/7.pdf. Дата звернення: травень, 30, 2017. 
[5] В. В. Корольський, Т. Г. Крамаренко, С. О. Семеріков, та С. В. Шокалюк, Інноваційні інформаційно-комунікаційні технології навчання математики. Кривий Ріг, Україна: Книжкове видавництво Кирєєвсього, 2009.

[6] И. В. Фуфачев, "Применение тьюторских практик в старших классах на уроках физики и математики", Теоретические и методологические проблемы современного образования, с. 141-143, 2015.

[7] Т. А. Кузьмина, и И. Н. Семенова, "Тьюторское сопровождение как важный компонент процесса обучения в условиях развития информационных и коммуникационных технологий", Педагогическое образование в России, № 5, с. 42-45, 2013.

[8] К. П. Осадча, "Інформаційно-комунікаційні технології здійснення тьюторської діяльності у системі шкільної освіти", Науково-педагогічний журнал «Молодь і ринок», №9 (128), с. 22-26, 2016.

[9] Н. А. Сторожук, О. Ф. Сальнікова, та Л. О. Ряба, "Структурно-функціональний аналіз діяльності тьютора в системі організації та супроводу навчально-виховного процесу у вищому навчальному закладі", Збірник наукових працьь Військового інституту Київського національного університету імені Тараса Шевченка, Вип. 4, с. 238-245, 2013.

[10] Э. О’Брайант, Стать тьютором. Вдохновляющий опыт тех, кто помогает учиться. Москва, Россия: Pecypc, 2012.

[11] "Адаптивное обучение, или несколько слов о Knewton". [Электронный ресурс]. Режим доступа: https://habrahabr.ru/company/npl/blog/244539.Дата звернення: чер. 1, 2017.

[12] GENEXIS 2.6 description. [Online]. Available:http://www.genexiseducation.com/genexis.Accessed on: May31, 2017.

[13] J. Hohenwarter, and M. Hohenwarter, Introduction to GeoGebra. [Online]. Available:https://static.geogebra.org/book/intro-en.pdf.Accessedon:May31, 2017.

[14] Using Wolfram|Alpha in the Classroom. [Online]. Available:http://www.wolframalpha.com/educators.Accessed on: May31, 2017.

[15] В. В. Осадчий, та О. В. Мартинюк А. с. 58859 Україна. Комп’ютерна програма «Навчальнотренувальний мобільний засіб для підготовки до ЗНО на базі ОС Android “Test”».

Матеріал надійшов до редакиї 07.06.2017 p.

\title{
ТЬЮТОРСКОЕ СОПРОВОЖДЕНИЕ ОБУЧЕНИЯ МАТЕМАТИКЕ СРЕДСТВАМИ ИНФОРМАЦИОННО-КОММУНИКАЦИОННЫХ ТЕХНОЛОГИЙ
}

\author{
Осадчая Екатерина Петровна \\ доцент, кандидат педагогических наук, доцент кафедры информатики и кибернетики \\ Мелитопольский государственный педагогический университет имени Богдана Хмельницкого, \\ г. Мелитополь, Украина \\ ORCID ID 0000-0003-0653-6423 \\ okp@mdpu.org.ua
}

\begin{abstract}
Аннотация. В статье описана деятельность тьютора в процессе сопровождения обучения математике на основе использования информационно-коммуникационных технологий (ИКТ). Автором проанализированы имеющиеся Интернет-ресурсы и мобильные приложения по математике, которые классифицированы по их функциональному назначению на группы: системы массовых открытых курсов, платформы для адаптивного обучения, видео-каналы, математические онлайн тренажеры, онлайн задачи, математические игры, математические порталы, онлайн платформы, математические сайты, математические онлайн среды, математические сервисы, мобильные приложения по математике (тренажеры, игры, генераторы примеров, программы-помощники, учебные комплексы, калькуляторы). В соответствии с возрастными категориями тьюторантов ИКТ по математике условно разделены на три группы: для младших школьников, учащихся средней школы и старшеклассников. Кратко описаны основные средства ИКТ в обучении математике. Представлен алгоритм построения тьюторского занятия с их использованием.
\end{abstract}

Ключевые слова: тьютор; математика; информационно-коммуникационные технологии; ресурсы Интернет; мобильные приложения. 


\title{
TUTOR SUPPORT OF TEACHING MATHEMATICS WITH INFORMATION AND COMMUNICATION TECHNOLOGIES
}

\author{
Kateryna P. Osadcha \\ associate professor, PhD (Pedagogy), associate professor of the Computer Science and Cybernetics Department \\ Melitopol State Pedagogical University named after Bohdan Khmelnytskyi, Melitopol, Ukraine \\ ORCID ID 0000-0003-0653-6423 \\ okp@mdpu.org.ua
}

\begin{abstract}
The paper describes the tutor activity in the process of mathematics teaching support on the basis of the use of information and communication technologies (ICT). The author has analysed the available Internet resources and mobile applications in mathematics, which are classified according to their functional purposes into groups: systems of mass open courses, platforms for adaptive learning, video channels, mathematical online simulators, online tasks, mathematical games, mathematical portals, online platforms, mathematical sites, mathematical online platforms, mathematical services, mobile applications in mathematics (simulators, games, generators of example, assistant programs, training complexes, calculators). In accordance with the student age categories mathematical information and communication technologies are divided into three groups: for elementary school students, secondary school students and high school students. The basic ICT tools for teaching mathematics are outlined. The algorithm for constructing tutorial classes with their application is presented.
\end{abstract}

Keywords: tutor; mathematics; information and communication technologies; Internet resources; mobile applications.

\section{REFERENCES (TRANSLATED AND TRANSLITERATED)}

[1] V.P. Sergeeva, I.S. Sergeeva, G.V. The Fortieth, and Y.V. Ziborov, Tutor in the educational space. Moscow, Russia: INFRA-M, 2016. (in Russian)

[2] M.I. Zhaldak, "The pedagogical potential of computer-oriented mathematics teaching systems". [Online]. Available:http://ii.npu.edu.ua/files/Zbirnik_KOSN/7/1.pdf. Accessed on: May, 26, 2017. (inUkrainian)

[3] E.F. Vinnichenko, "Development of creative abilities of senior pupils in teaching information technologies for solving mathematical problems", Ph.D. thesis, National Pedagogical Dragomanov Univ., Kiev, 2006. (inUkrainian)

[4] T.O. Oleinik, "Using ICT for developing critical thinking". [Online]. Available: http://enpuir.npu.edu.ua/bitstream/123456789/1300/1/7.pdf. Accessed on: May, 30, 2017. (inUkrainian)

[5] V.V. Korolskyy, T.G. Kramarenko, S.O. Semerikov, and S.V. Shokalyuk. Innovative information and communication technologies of teaching mathematics.KryvyiRih, Ukraine: Book Publishers Kyryeyevsoho, 2009. (in Ukrainian)

[6] I.V. Fufachev, "The application of tutoring practices in the upper grades at lessons of physics and mathematics", Teoreticheskiei metodologicheskie problemi sovremennogo obrazovaniya, c.141-143, 2015. (in Russian)

[7] T.A. Kuzmina, and I.N. Semenov, "Tutor support as an important component of the learning process under the conditions of information and communication technologies development ", Pedagogicheskoeobrazovanie v Rossii, № 5, c. 42-45, 2013. (in Russian)

[8] K.P. Osadcha, "Information and communication technologies of the implementation of tutor activities in the school educational system",Naukovo-pedagogichniy zhurnal «Molod I rinok», №9 (128), c. 2226,2016. (in Ukrainian)

[9] N.A. Storozhuk, O.F. SalnIkova, and L.O. Ryaba, "Structural and functional analysis of the tutor in the organization and support of the educational process in higher education", Zbirnik naukovih prats Viyskovogo Institutu Kiyivskogo natsionalnogo universitetu imeni Tarasa Shevchenka, vol. 44, c. 238245, 2013. (in Ukrainian)

[10] E O'Briant, Be a Great Tutor. The inspiring guide to tutoring all ages. Moscow, Russia: Resurs, 2012. (in Russian)

[11] Adaptive learning, or several words about Knewton. [Online]. Available:https://habrahabr.ru/company/npl/blog/244539. Accessedon: чеp. 1, 2017. (in Russian)

[12] GENEXIS 2.6 description. [Online]. Available:http://www.genexiseducation.com/genexis. Accessedon: May 31, 2017. (in English) 
[13] J. Hohenwarter, and M. Hohenwarter, Introduction to GeoGebra. [Online]. Available:https://static.geogebra.org/book/intro-en.pdf. Accessedon: May 31, 2017. (in English)

[14] Using Wolfram|Alpha in the Classroom. [Online]. Available:http://www.wolframalpha.com/educators. Accessedon: May 31, 2017. (in English)

[15] V.V. Osadchyi, and O.A. Martyniuk, Certificate of authorship 58859, Ukraine.Computer program «Education and training tool for preparation for external independent testingon the basis of the OS Android "Test "». (inUkrainian)

\section{(c) DY-NC-SA}

This work is licensed under Creative Commons Attribution-NonCommercial-ShareAlike 4.0 International License. 